\title{
PENGEMBANGAN ALAT UKUR SKALA CITRA TUBUH
}

\author{
Aina Putri Khairani, Hannan, dan Laura Amalia \\ Fakultas Psikologi dan Ilmu Sosial Budaya,Magister Profesi Psikologi, Universitas Islam Indonesia
}

Email: khairanina12@gmail.com

\begin{abstract}
Abstrak
Penelitian ini bertujuan untuk menguji validitas dan mengembangkan alat ukur skala citra tubuh. Pengembangan alat ukur ukur ini berdasarkan teori Cash (2012) yang terdiri dari 5 aspek yaitu evaluasi penampilan, orientasi penampilan, kepuasan terhadap bagian-bagian tubuh, kecemasan menjadi gemuk dan pengkategorian ukuran tubuh. Responden dalam penelitian ini berjumlah 196 siswa SMK di Kecamatan Semarang Barat dengan teknik sampling cluster random sampling. Dari EFA diperoleh nilai KMO 0,762 dan mengalami perubahan aspek menjadi 2 aspek yakni evaluasi penampilan dan kepuasan terhadap penampilan.
\end{abstract}

Kata kunci : citra tubuh, exploratory factor analysis, validasi

\section{DEVELOPMENT OF THE MEASURE OF THE BODY IMAGE SCALE}

\begin{abstract}
This study aims to test the validity and develop body image scale measurement tools. The development of this measuring instrument is based on Cash's theory (2012) which consists of 5 aspects namely appearance evaluation, appearance orientation, satisfaction with body parts, anxiety of being fat and categorizing body size. Respondents in this study numbered 196 vocational students in the District of West Semarang with cluster random sampling technique. From the EFA obtained KMO value of 0.762 and experienced changes in aspects into 2 aspects namely appearance evaluation and satisfaction with appearance.
\end{abstract}

Key Words: body image, exploratory factor analysis, validation.

\section{Pendahuluan}

Citra tubuh adalah sebuah penilaian individu yang bersifat subjektif yang berkaitan dengan bentuk tubuh, berat badan dan hal lain yang berhubungan dengan penampilan fisik individu (Smolak \& Thompson, 2011). Citra tubuh seseorang individu dapat bersifat negatif maupun positif (Grogan, 2008). Penilaian tersebut terbentuk melalui persepsi, perasaan, imajinasi, lingkungan sekitar, suasana hati dan pengalaman fisik (Smolak \& Thompson, 2011). Castle (2007) juga menjelaskan citra tubuh bukan hanya persepsi subjektif yang berasal dari dalam diri individu, tetapi juga bagaimana lingkungan sekitarnya atau orang lain menilai penampilan fisik dari individu tersebut.

Pandangan orang lain mengenai diri sendiri dapat mempengaruhi citra diri individu. Hal itu sesuai dengan faktor yang mempengaruhi citra diri yang disebutkan oleh (Mukhlis, 2013). Menurut Mukhlis (2013), citra diri memiliki 5 faktor, yaitu: (a) opini orang sekitar; (b) pelecehan seksual dan etnis; (c) stigma; (d) kualitas sosial; (e) peralihan fisik pada masa puber, menopause serta kehamilan; (f) sosialisasi; (g) bagaimana pemikiran individu akan diri; (h) kekerasan secara lisan, fisik, atau seksual; dan (i) keadaan tubuh, seperti sakit atau cacat.

Faktor yang mempengaruhi citra tubuh lainnya juga dijelaskan oleh (Cash \& Pruzinsky, 2002) yakni jenis kelamin, media massa dan hubungan interpersonal dapat mempengaruhi citra tubuh seseorang. Jenis kelamin dapat mempengaruhi citra tubuh seseorang. Hal itu karena ketidakpuasan tubuh lebih sering dialami oleh perempuan. Ketidakpuasan ini yang membuat perempuan lebih 
mempunyai citra tubuh yang buruk jika disamakan dengan laki-laki. Media massa dapat mempengaruhi citra tubuh dalam hal standart kecantikan yang dilihat di televisi. Figur yang dianggap ideal tersebut dapat mempengaruhi penilaian terhadap citra tubuh individu. Hubungan interpersonal mempengaruhi individu dalam menilai tubuhnya dan feedback yang diberikan membuat individu cemas akan opini orang sekitar atas dirinya.

Dalam konsep citra tubuh, terdapat aspek yang digunakan untuk mengukur tingkat kepuasan individu terhadap citra tubuh yang dimiliki individu. Aspek citra tubuh salah satunya dikembangkan oleh (Thomas Cash, 2012) yaitu evaluasi penampilan, orientasi penampilan, kepuasan terhadap bagian-bagian tubuh, kecemasan menjadi gemuk dan pengkategorian ukuran tubuh. Menurut Smolak \& Thompson (2011) menjelaskan aspek-aspek dalam citra tubuh yaitu: a) Persepsi terhadap bagian-bagian tubuh dan penampilan secara keseluruhan. Bentuk tubuh merupakan suatu simbol dari diri seorang individu, karena dalam hal tersebut individu dinilai oleh orang lain dan dinilai oleh dirinya sendiri. Selanjutnya bentuk tubuh serta penampilan baik dan buruk dapat mendatangkan perasaan senang atau tidak senang terhadap bentuk tubuhnya sendiri. b) Aspek perbandingan dengan orang lain. Adanya penilaian sesuatu yang lebih baik atau lebih buruk dari yang lain, sehingga menimbulkan suatu prasangka bagi dirinya keorang lain, hal-hal yang menjadi perbandingan individu ialah ketika harus menilai penampilan dirinya dengan penampilan fisik orang lain. c) Aspek sosial budaya (reaksi terhadap orang lain). Seseorang dapat menilai reaksi terhadap orang lain apabila dinilai orang itu menarik secara fisik, maka gambaran orang itu akan menuju hal-hal yang baik untuk menilai dirinya.

Konsep diri adalah pandangan pribadi individu tentang individu sendiri (Calhoun \& Acocella, 1995). Menurut Hurlock (2001) konsep diri adalah suatu sikap yang menjadikan dirinya sebagai objek yang meliputi aspek fisik, emosi, sosial dan intelektual. Fitts (Agustiani, 2006) konsep diri adalah diri individu sendiri yang dilihat, dirasakan dan yang telah dialami oleh individu tersebut Calhoun \& Acocella (1995) terdapat beberapa faktor pembentuk konsep diri, khususnya konsep diri remaja, yakni a) Orangtua sebagai kontak sosial paling awal yang dialami dan yang paling kuat, apa yang dikomunikasikan oleh orangtua pada anak lebih menancap daripada informasi lain yang diterima anak sepanjang hidupnya b) Kawan sebaya yang menempati kedudukan kedua setelah orangtuanya dalam mempengaruhi konsep diri, apalagi perihal penerimaan atau penolakan, peran yang diukir anak dalam kelompok teman sebayanya mungkin mempunyai pengaruh yang dalam pada pandangan tentang dirinya sendiri. c) Masyarakat yang menganggap penting fakta-fakta kelahiran di mana akhirnya penilaian ini sampai kepada anak dan masuk ke dalam konsep diri d) Belajar dimana muncul konsep bahwa konsep diri kita adalah hasil belajar, dan belajar dapat didefinisikan sebagai perubahan psikologis yang relatif permanen yang terjadi dalam diri kita sebagai akibat dari pengalaman. Menurut Calhoun \& Acocella (1995) aspek konsep diri adalah A) Pengetahuan dimensi pertama dari konsep diri adalah apa yang kita ketahui tentang diri kita sendiri. Hal hal yang menggambarkan kita seperti : usia, jenis kelamin, kebangsaan, suku bangsa, profesi dan lain sebagainya. b) Harapan, dimensi ini adalah hal yang penting dalam konsep diri. Harapan atau tujuan masing masing individu berbeda. Apapun harapan atau tujuan seseorang, hal tersebut yang akan membuat individu bergerak menuju masa depan dan menuntun gerakan kita saat kita pergi. c) Evaluasi seseorang berada pada prasangka orang atas dirinya sendiri setiap hari

Hurlock (2001) penerimaan diri adalah kemampuan menerima segala sesuatu yang ada pada diri individu (kelebihan dan kekurangan) sehingga apabila terjadi hal yang kurang menyenangkan pada individu tersebut mampu berfikir secara realistis mengenai baik buruknya hal yang terjadi tanpa memunculkan perasaan rendah diri, malu dan rasa tidak aman. Menurut Hurlock (2001) faktor yang memengaruhi penerimaan diri : a) Aspirasi yang realitas. Individu yang menerima dirinya adalah individu yang melihat dirinya secara realistis dan tidak memilki keinginan yang tidak mungkin tercapai b) Keberhasilan. Agar seseorang menerima dirinya, maka orang tersebut harus mengembangkan faktor peningkatan keberhasilan sehingga berpotensi berkembang secara maksimal 
c) Wawasan diri. Penerimaan diri yang tinggi bisa dimiliki jika individu memiliki kemampuan dan keinginan untuk menilai diri sendiri secara realistis dan menerima kelemahan serta kelebihan diri sendiri d) Wawasan sosial. Kemampuan melihat diri pada individu seperti pandangan orang lain tentang diri individu tersebut menjadi suatu. Menurut Supratiknya (2016), aspek penerimaan diri antara lain a) Kesediaan untuk membuka diri. Ditunjukkan dengan ketersediaan untuk membuka atau mengungkakan pikiran, perasaan dan reaksi individu kepada orang lain. Individu harus melihat dirinya sendiri secara realita bukan apa yang dia bayangkan. Terciptanya penerimaan diri yang baik dilihat dari bagaimana individu menghargai dan menyayangi dirinya sendiri dan terbuka dengan orang lain b) Kesehatan psikologis. Hal ini berhubungan dengan kualitas perasaan terhadap diri sendiri. Individu yang sehat secara psikologis memandang dirinya sebagai orang yang disenangi, mampu, berharga dan diterima oleh orang lain. Untuk dapat mengembangkan penerimaan diri maka harus memberikan pemahaman tentang kesehatan psikologis. c) Penerimaan terhadap orang lain. Individu yang mampu menerima diri sendiri akan mampu juga menerima orang lain begitu sebaliknya, apabila individu menolak dirinya sendiri maka dia akan menolak orang lain juga.

Penelitian Hannan pada tahun 2018 terkait citra tubuh menjelaskan bahwa citra tubuh memiliki hubungan yang positif terhadap penerimaan diri dan konsep diri. Hal itu berarti semakin tinggi citra tubuh seorang individu, semakin tinggi pula konsep diri dan penerimaan diri seorang individu tersebut. Begitu pula sebaliknya, semakin rendah citra tubuh individu, semakin rendah pula konsep diri dan penerimaan diri individu.

Dalam penelitian tersebut, Hannan (2018) menyusun alat ukur tentang citra tubuh yang dikembangkan menggunakan aspek yang disampaikan oleh Cash (2012). Aspek tersebut terdiri dari evaluasi penampilan, orientasi penampilan, kepuasan terhadap bagian-bagian tubuh, kecemasan menjadi gemuk dan pengkategorian ukuran tubuh. Alat ukur tersebut terdiri dari 13 aitem dengan reliabilitas 0,696 yang diuji menggunakan Alpha Cronbach.

Berdasarkan penjelasan diatas peneliti melihat perlu adanya alat ukur mengenai citra tubuh yang tervalidasi. Pada dasarnya, terdapat alat ukur lain mengenai citra tubuh yang sering digunakan peneliti lain untuk mengukur citra tubuh. Alat ukur tersebut disusun oleh Cash pada tahun 2000 yang diberi nama MBSRQ-AS. Pertimbangan peneliti lebih memilih menggunakan alat ukur yang disusun oleh Hannan (2018) adalah pada alat ukur MBSRQ-AS memiliki karakteristik subjek yang berbeda dengan penelitian yang dilakukan oleh Hannan. Selain itu, alat ukur tersebut disusun di luar negeri, sehingga dimungkinkan tidak bebas budaya. Tahun penyusunan MBSRQ-AS juga terlampau lama, yaitu tahun 2000 yang mana itu 20 tahun lalu. Berdasarkan pertimbangaan tahun dibuatnya alat ukur tersebut peneliti berpikir alat ukur tersebut tidak mampu menyesuaikan dengan pola pikir remaja dewasa ini.Penelitian ini bertujuan untuk menganalisis faktor skala citra tubuh menggunakan alat ukur yang disusun oleh Hannan (2018) berdasarkan aspek dari Cash (2012). Penyusunan dan Pengembangan Alat Ukur Citra Tubuh. Penyusunan dan pengembangan alat ukur psikologis meliputi beberapa tahap, sebelum kepada tahap penyusunan dan pengembangan alat ukur, akan dijelaskan terlebih dulu mengenai pengukuran. Pengukuran adalah bagian esensial kegiatan keilmuan. Pengukuran adalah cabang ilmu dari terapan statistik yang memiliki tujuan untuk memahami dasardasar pengembangan tes yang lebih baik sehingga dihasilkan pengembangan tes yang bermanfaatsecara optimal, reliabel dan valid (Singh, 2006).

Alur kerja dalam penyusunan skala citra tubuh meliputi : penetapan tujuan, menetapkan domain yang akan diukur, menyusun atribut dan indikator perilaku, menyusun blueprint, menulis aitem, penskalaan dan penentuan skor, seleksi aitem, uji coba alat ukur dan analisis aitem.

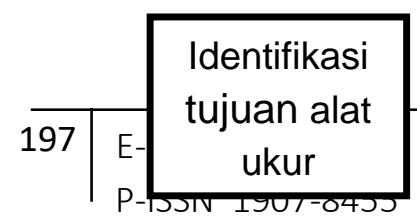




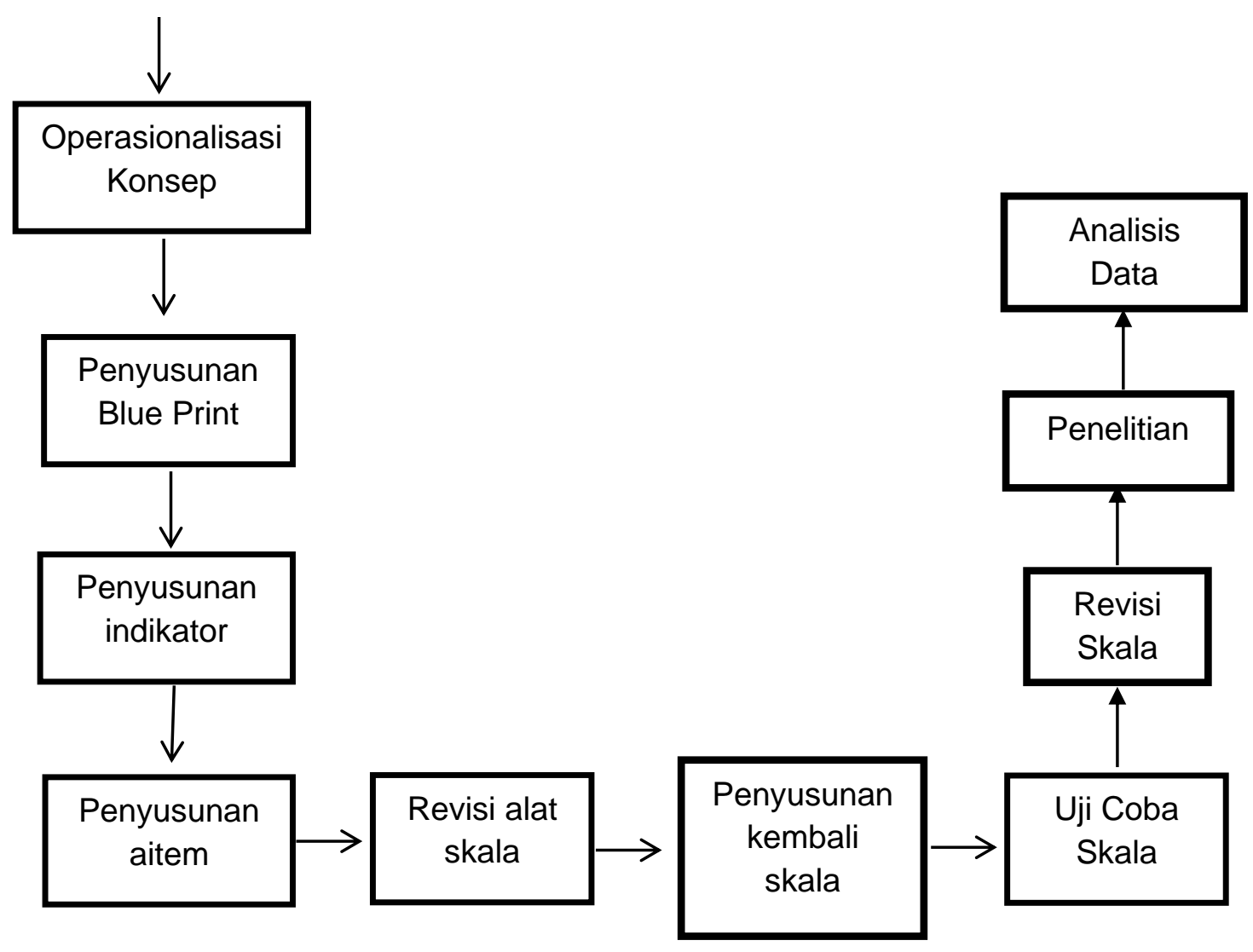

Gambar 1. Bagan Alur Pengembangan Alat Ukur Citra Tubuh

\section{Metode}

Penelitian ini menggunakan pendekatan kuantitatif untuk melakukan penyusunan dan pengembangan serta untuk mengetahui nilai reliabilitas, validitas dan kualitas dari setiap aitem pertanyaan yang mengukur citra tubuh. Penelitian ini menggunakan metode pengembangan model teoritis berdasarkan data empirik dan teori yang sesuai dengan tema penelitian. Validitas yang dilakukan pada penelitian ini adalah validitas isi dan validitas konstruk. Penelitian ini berjenis konstruk ala ukur psikologi. Konstruk bertujuan melihat propertis psikometri alat ukur, aitem yang disusun menjadi alat ukur yang siap digunakan. Variabel uatama dalam penelitian ini adalah citra tubuh. Subjek dalam penelitian ini berjumlah 196 siswa dari 3 sekolah di Kecamatan Semarang Barat. Teknik pengambilan sampel digunakan cluster sampling. Teknik cluster random sampling merupakan teknik penentuan sampel dengan berdasarkan kelompok atau cluster dari populasi (Sugiono, 2009). Alasan peneliti menggunakan cluster random sampling karena yang akan dijadikan subjek penelitan adalah kelompok pelajar SMK kelas X dan XII. Pengumulan data dalam penelitian ini meliputi :

Tahap 1 : Uji Coba Skala. Pada tahap ini peneliti menyebarkan alat ukur citra tubuh kepada 105 siswa SMK yang diisi lengkap. Tahap ini dilakukan untuk mendapatkan data mengenai validitas dan reliabilitas alat ukur.

Validitas internal. Validasi dalam skala ini menggunakan validitas isi. Validitas isi adalah validitas yang ditegakkan atau revisi pada setiap butir pernyataan maupun secara keseluruhan melalui para profesional judgement (penelaah profesional) (Azwar, 2012). Profesional judgement dalam penelitian ini adalah dosen pembimbing skripsi. Pernyataan yang terdapat dalam validasi 
penelitian ini bertujuan untuk mengetahui sejauh mana pernyataan aitem-aitem mewakili komponen dalam keseluruhan area isi objek yang hendak diukur (aspek representatif) dan sejauh mana pernyataan aitem-aitem mencerminkan ciri perilaku yang hendak diukur (aspek relevansi).

Penelitian. Peneliti mengambil data terhadap 196 siswa SMK dan kemudian melakukan analisis data. Pengukuran citra tubuh disusun oleh peneliti berdasarkan teori Cash (2012) yang terdiri dari 16 aitem dengan 5 alternatif jawaban yakni 1 untuk sangat tidak sesuai, 2 untuk tidak sesuai, 3 untuk netral, 4 untuk sesuai dan 5 untuk sangat sesuai. Reliabilitas mengarah pada kepercayaan atau konsistensi hasil ukur yang memiliki makna seberapa tinggi kecermatan pengukuran. Alat ukur dapat dikatakan berkualitas apabila mampu menghasilkan skor yang cermat dengan eror pengukuran kecil (reliabel) (Azwar, 2012).

Koefisien reliabilitas (rxx) berada dalam rentangan angka 0 sampai dengan 1.00 . Hal ini berarti bahwa koefisien reliabilitas yang besarnya semakin mendekati angka 1.00, maka semakin reliabel alat ukur tersebut. Adanya konsistensi yang sempurna tidak dapat diharapkan terjadi pada pengukuran aspek-aspek psikologis. Hal ini dikarenakan manusia merupakan sumber eror yang potensial dalam pengukuran psikologis.

Dalam penelitian ini, ada beberapa teknik analisis data yang akan dilakukan yakni Alpha Cronbach dan Confirmatory Factor Analysis dengan menggunakan bantuan program SPSS versi 23.0 for widows.

\section{Uji Coba Skala}

Berikut ini adalah hasil hitungan uji daya beda aitem dan reliabilitas untuk setiap skala:

Skala Citra tubuh

Skala citra tubuh memiliki 5 aspek dan setiap aspek memiliki 2 indikator. Indikator tersebut digunakan untuk mempermudah peneliti dalam membuat pernyataan. Total aitem pada skala citra tubuh berjumlah 40 aitem yang terdiri dari 20 aitem favorable dan 20 aitem unfavorable. Hasil uji daya beda aitem yang dimiliki oleh 40 aitem menunjukkan bahwa 14 aitem memiliki indeks daya beda tinggi dan 26 aitem memiliki indeks daya beda rendah. Distribusi aitem daya beda tinggi dan daya beda rendah dapat dilihat pada tabel berikut :

Tabel 1. Sebaran Aitem Berdaya Beda Tinggi dan Rendah pada Skala Citra tubuh

\begin{tabular}{llll}
\hline \multirow{2}{*}{ Aspek } & Aitem & Jumlah \\
\cline { 2 - 4 } & Favorabel & Unfavorabel & Aitem \\
\hline Evaluasi penampilan & $1^{*}, 2^{*}, 5,6$ & $3^{*}, 4^{*}, 7,8$ & 8 \\
Orientasi penampilan & $9^{*}, 10^{*}, 13^{*}$ & $11^{*}, 12^{*}, 14^{*}, 15^{*}, 16$ & 8 \\
Kepuasan terhadap bagian tubuh & $17^{*}, 18^{*}, 21,22$ & $19^{*}, 20^{*}, 23,24$ & 8 \\
Kecemasan menjadi gemuk & $25^{*}, 26^{*}, 29^{*}, 30^{*}$ & $27,28^{*}, 31^{*}, 32^{*}$ & 8 \\
Pengkategorian ukuran tubuh & $33,34,37^{*}, 38^{*}$ & $35^{*}, 36^{*}, 39^{*}, 40$ & 8 \\
Total & $\mathbf{2 0}$ & $\mathbf{2 0}$ & $\mathbf{4 0}$ \\
\hline
\end{tabular}

Keterangan: *aitem yang gugur/daya beda rendah

Koefisien daya beda aitem skala yang memiliki daya beda tinggi pada skala citra tubuh berkisar antara 0,277 hingga 0,564. Indeks daya beda rendah memiliki koefisien daya beda aitem berkisar antara $-0,360$ hingga 0,249. Kriteria pemilihan aitem untuk korelasi aitem total menggunakan batasan rix $\geq 0,25$ karena jumlah aitem yang lolos belum mencukupi jumlah yang diinginkan ketika menggunakan batsan $\geq 0,25$. Estimasi reliabilitas skala citra tubuh diperoleh melalui teknik Alpha Cronbach dengan angka koefisien reliabilitas Alpha sebesar 0,613 sehingga alat ukur skala citra tubuh dalam hal ini dinyatakan reliabel. 


\section{Skala Konsep Diri}

Skala konsep diri memiliki 4 aspek dan setiap aspek memiliki beberapa indikator. Indikator tersebut digunakan untuk mempermudah peneliti dalam membuat pernyataan. Total aitem pada skala konsep diri berjumlah 24 aitem yang terdiri dari 12 aitem favorable dan 12 aitem unfavorable. Hasil uji daya beda aitem yang dimiliki oleh 24 aitem menunjukkan bahwa 16 aitem memiliki indeks daya beda tinggi dan 8 aitem memiliki indeks daya beda rendah. Distribusi aitem daya beda tinggi dan daya beda rendah dapat dilihat pada tabel berikut:

Tabel 2. Sebaran Aitem Berdaya Beda Tinggi dan Rendah pada Skala Konsep Diri

\begin{tabular}{llll}
\hline \multirow{2}{*}{ Aspek } & \multicolumn{2}{l}{ Aitem } & \multirow{2}{*}{ Jumlah Aitem } \\
\cline { 2 - 3 } & Favorabel & Unfavorabel & \\
\hline Fisik & $1^{*}, 2^{*}, 3$ & $4^{*}, 5,6^{*}$ & 6 \\
Psikis & $7,8,9$ & $10,11,12$ & 6 \\
Sosial & $13^{*}, 14^{*}, 15^{*}$ & $16,17,18$ & 6 \\
Moral & $19,20,21$ & $22,23,24^{*}$ & 6 \\
Total & $\mathbf{1 2}$ & $\mathbf{1 2}$ & $\mathbf{2 4}$ \\
\hline
\end{tabular}

Keterangan: *aitem yang gugur/daya beda rendah

Koefisien daya beda aitem skala yang memiliki daya beda tinggi pada skala konsep diri berkisar antara 0,252 hingga 0,533. Indeks daya beda rendah memiliki koefisien daya beda aitem berkisar antara $-0,055$ hingga 0,243. Kriteria pemilihan aitem untuk korelasi aitem total menggunakan batasan rix $\geq 0,25$ karena jumlah aitem yang lolos belum mencukupi jumlah yang diinginkan ketika menggunakan batasan $\geq 0,25$. Estimasi reliabilitas skala konsep diri diperoleh melalui teknik Alpha Cronbach dengan angka koefisien reliabilitas Alpha sebesar 0,738 sehingga alat ukur skala konsep diri dalam hal ini dinyatakan reliabel.

Skala Penerimaan Diri

Skala penerimaan diri memiliki 3 aspek dan setiap aspek memiliki beberapa indikator. Aspek kesediaan membuka diri memiliki 2 indikator, aspek kesehatan psikologis dan aspek penerimaan terhadap orang lain memiliki 4 indikator. Indikator tersebut digunakan untuk mempermudah peneliti dalam membuat pernyataan. Total aitem pada skala penerimaan diri berjumlah 31 aitem yang terdiri dari 15 aitem favorable dan 16 aitem unfavorable. Hasil uji daya beda aitem yang dimiliki oleh 31 aitem menunjukkan bahwa 21 aitem memiliki indeks daya beda tinggi dan 10 aitem memiliki indeks daya beda rendah. Distribusi aitem daya beda tinggi dan daya beda rendah dapat dilihat pada tabel berikut:

Tabel 3. Sebaran Aitem Berdaya Beda Tinggi dan Rendah pada Skala Penerimaan Diri

\begin{tabular}{cc|c}
\hline Aspek & Aitem & \multicolumn{2}{c}{ Jumlah Aitem } \\
\hline & E-ISSN 2656-4173 & 200
\end{tabular}




\begin{tabular}{|c|c|c|c|}
\hline & Favorabel & Unfavorabel & \\
\hline $\begin{array}{ll}\text { Kesediaan } & \text { Untuk } \\
\text { membuka diri } & \end{array}$ & $1^{*}, 2,5$ & $3^{*}, 4^{*}, 6^{*}$ & 6 \\
\hline Kesehatan psikologis & $\begin{array}{l}7,8,9,13^{*}, 14, \\
17^{*}, 20,21\end{array}$ & $\begin{array}{l}10,11^{*}, 12,15,16^{*}, \\
18,19,22,23\end{array}$ & 17 \\
\hline $\begin{array}{l}\text { Peneriman kepada orang } \\
\text { lain }\end{array}$ & $24^{*}, 26,28,30^{*}$ & $25,27,29,31$ & 8 \\
\hline Total & 15 & 16 & 31 \\
\hline
\end{tabular}

Keterangan: *aitem yang gugur/daya beda rendah

Koefisien daya beda aitem skala yang memiliki daya beda tinggi pada skala penerimaan diri berkisar antara 0,310 hingga 0,556. Indeks daya beda rendah memiliki koefisien daya beda aitem berkisar antara 0,043 hingga 0,206 . Kriteria pemilihan aitem untuk korelasi aitem total menggunakan batasan rix $\geq 0,25$ karena jumlah aitem yang lolos belum mencukupi jumlah yang diinginkan ketika menggunakan batasan $\geq 0,25$. Estimasi reliabilitas skala penerimaan diri diperoleh melalui teknik Alpha Cronbach dengan angka koefisien reliabilitas Alpha sebesar 0,792 sehingga alat ukur skala penerimaan diri dalam hal ini dinyatakan reliabel.

\section{Hasil}

\section{Uji Normalitas}

Berdasarkan uji normalitas yang diperoleh dari data citra tubuh menunjukkan bahwa nilai KSZ yaitu $>0,05$ yang berarti distribusi normal.

\section{Uji Reliabilitas}

Estimasi reliabilitas skala citra tubuh dari 13 aitem diperoleh melalui teknik Alpha Cronbach dengan angka koefisien reliabilitas Alpha sebesar 0,696 sehingga alat ukur skala citra tubuh dalam hal ini dinyatakan reliabel skala ini dapat digunakan untuk asesmen maupun untuk pengambilan data penelitian mengenai citra tubuh.

Tabel 4. Skor Reliabilitas Skala Citra Tubuh

\begin{tabular}{|r|r|r|}
\hline $\begin{array}{c}\text { Cronbach's } \\
\text { Alpha }\end{array}$ & $\begin{array}{c}\text { Cronbach's } \\
\text { Alpha Based on } \\
\text { Standardized } \\
\text { Items }\end{array}$ & N of Items \\
\hline .696 & .718 & 13 \\
\hline
\end{tabular}

Tabel 5. Skor Kaiser-Meyer-Olkin dan Bartlett's test of Aphericity 


\begin{tabular}{llc}
\hline $\begin{array}{l}\text { Kaiser-Meyer-Olkin } \\
\text { Sampling Adequacy }\end{array}$ & Measure of & 0,762 \\
$\begin{array}{l}\text { Bartlett's Test of } \\
\text { Sphericity }\end{array}$ & Approx. Chi-Square & 374,019 \\
& Df & 36 \\
& Sig. & 0,000 \\
\hline
\end{tabular}

Berdasarkan tabel 2, diketahui bahwa besaran nilai Nilai KMO Measure of Sampling Adequacy sebesar 0,762 dan Barlett Test of Sphericity sebesar 374,019 dengan taraf signifikansi $p$ sebesar 0,000 $(<0,005)$ Dengan KMO dan signifikansi tersebut, menunjukkan bahwa analisis faktor dapat dilakukan untuk memperoleh persentase total varians yang dapat dijelaskan yang dapat dilihat pada Tabel 3. Apabila nilai KMO lebih besar dari 0,7 dengan signifikansi $<0,005$ menunjukkan bahwa butir aitem berkorelasi tingii sehingga dapat dilakukan analisis faktor. Costello \& Osborne (2005), menyatakan bahwa struktur faktor telah murni atau fit jika faktor loading lebih besar dari pada 0,3, tidak ada crossloading (satu aitem memiliki lebih dari 1 loading factor) dan dalam satu faktor minimal ada 3 aitem.

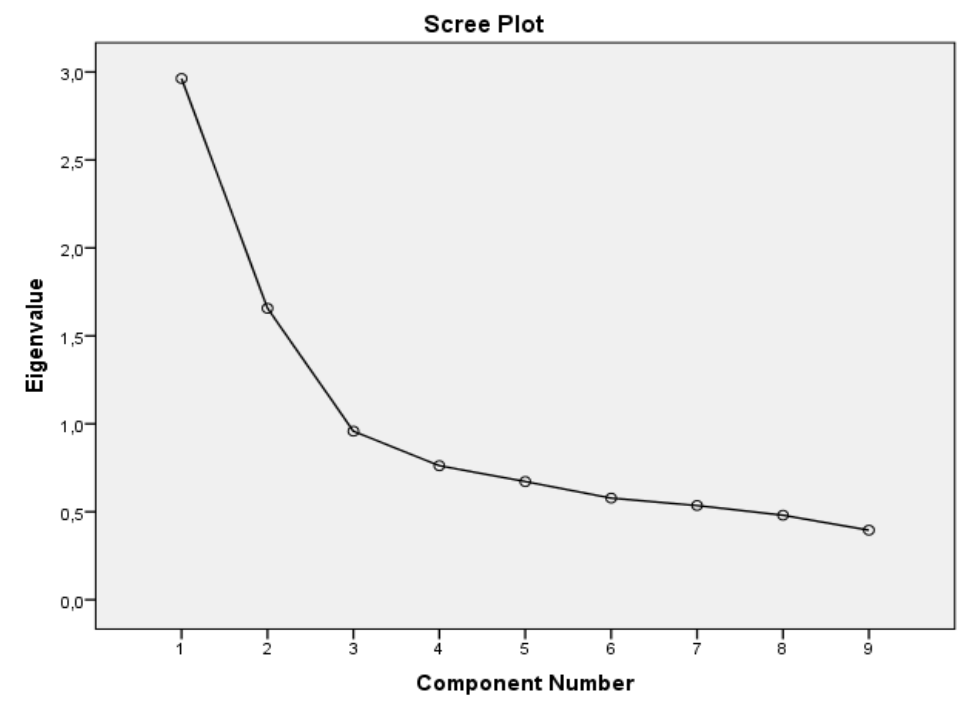

Gambar 2. Grafik Scree Plot

Berdasarkan pada grafik, menunjukkan bahwa terdapat 3 titik component yang memiliki nilai component yang memiliki Eigenvalue $>1$ sehingga dapat diartikan bahwa ada 2 faktor yang terbentuk. 


\begin{tabular}{|c|c|c|}
\hline \multirow{2}{*}{ Aitem } & \multicolumn{2}{|c|}{ Muatan Faktor } \\
\hline & 1 & 2 \\
\hline Saya tidak percaya diri dengan bentuk tubuh saya & 0,734 & \\
\hline $\begin{array}{l}\text { Saya cemburu dengan orang lain yang penampilan mereka lebih } \\
\text { menarik }\end{array}$ & 0,722 & \\
\hline $\begin{array}{l}\text { Saya tidak menyukai bentuk tubuh saya karena berbeda dengan } \\
\text { orang lain }\end{array}$ & 0,710 & \\
\hline Saya merasa penampilan saya buruk & 0,640 & \\
\hline $\begin{array}{l}\text { Saya merasa tidak nyaman dengan bentuk tubuh saya yang tidak } \\
\text { ideal }\end{array}$ & 0,627 & \\
\hline Saya menyukai semua bagian tubuh saya & & 0,762 \\
\hline Saya merasa nyaman dengan bentuk tubuh saya saat ini & & 0,731 \\
\hline Saya bersyukur dengan kondisi tubuh saya saat ini & & 0,723 \\
\hline Secara keseluruhan, penampilan saya menarik & & 0,656 \\
\hline Eigenvalue & 2,963 & 1,657 \\
\hline Varians dalam $\%$ & 27,507 & 23,823 \\
\hline Kumulatif varians dalam \% & 27,507 & 51,330 \\
\hline Jumlah Aitem & 5 & 4 \\
\hline
\end{tabular}

Keterangan: 1 = dimensi evaluasi penampilan; 2 = dimensi kepuasan terhadap penampilan;

Tabel 3 memperlihatkan bahwa analisis faktor eksploratori yang dilakukan terhadap skala citra tubuh menghasilkan dua faktor. Alat ukur memiliki total variasi yang dapat dijelaskan sebesar 51,330\%. Kontribusi dari dimensi 1 sebesar 27,507\%, dan dimensi 2 sebesar 23,823\%. Dari persentase tersebut terlihat bahwa dimensi 1 yang memberikan kontribusi terbesar di antara kedua aspek dari skala citra tubuh.

\section{Penamaan Faktor}

Berdasarkan tabel 3 dilakukaan penamaan faktor. Penamaan faktor diberikan berdasarkan pengelompokkan aitem yang ditunjukkan oleh muatan faktor. Kedua faktor tersebut menjadi dimensi dari konstruk citra tubuh. Faktor pertama adalah faktor yang terbesar variansnya dalam menjelaskan variabel. Aitem yang termasuk ke dalam dimensi 1 dengan melihat besarnya faktor loading yaitu aitem 8, 4, 3, 9 dan 13. Berdasarkan pada konten pernyataannya maka faktor pertama dinamakan evaluasi penampilan. Aitem yang termasuk ke dalam dimensi 2 adalah 6, 2, 1, dan 7 dengan memperhatikan konten pernyataannya maka dimensi kedua diberi nama kepuasan terhadap penampilan. Dengan demikian, dapat disimpulkan bahwa skala citra tubuh terdiri dari 2 dimensi yang meliputi evaluasi penampilan, dan kepuasan terhadap penampilan.

Loading Faktor 
Berdasarkan tabel 2 dapat diketahui muatan faktor atau factor loading yang dimiliki tiap aitem setelah dilakukan rotasi dengan metode varimax. Metode varimax berusaha untuk menjadikan muatan faktor menjadi tinggi atau mendekati 1 atau -1 pada salah satu faktor. Hasil rotasi dengan metode varimax menghasilkan muatan-muatan faktor sebagai berikut.

Pada dimensi 1, aitem yang memiliki korelasi yang kuat dengan dimensi 1 terdiri dari 5 aitem yaitu "Saya tidak percaya diri dengan bentuk tubuh saya" $(0,734)$, "Saya cemburu dengan orang lain yang penampilan mereka lebih menarik" $(0,722)$, "Saya tidak menyukai bentuk tubuh saya karena berbeda dengan orang lain" $(0,710)$, "Saya merasa penampilan saya buruk" $(0,640)$, dan aitem "Saya merasa tidak nyaman dengan bentuk tubuh saya yang tidak ideal" $(0,627)$.

Kemudian, pada dimensi 2, aitem yang memiliki korelasi yang kuat dengan dimensi 2 terdiri dari 4 aitem yaitu "Saya menyukai semua bagian tubuh saya" $(0,732)$, "Saya merasa nyaman dengan bentuk tubuh saya saat ini" $(0,731)$, "Saya bersyukur dengan kondisi tubuh saya saat ini" $(0,723)$ dan aitem "Secara keseluruhan, penampilan saya menarik" $(0,656)$.

\section{Kesimpulan}

Berdasarkan analisis faktor yang telah dilakukan maka dapat disimpulkan bahwa terdapat 2 faktor pembangun citra tubuh yaitu evaluasi penampilan dan kepuasan terhadap penampilan.

\section{Saran}

Peneliti selanjutnya disarankan agar lebih mendalami faktor-faktor yang mempengaruhi citra tubuh terutama faktor media massa dengan metode kualitatif agar lebih mendalami pandangan subjek mengenai citra tubuh. Mahasiswa Pelajar SMK Diharapkan mampu untuk mempertahankan dan meningkatkan konsep diri dan penerimaan diri sehingga citra tubuh semakin positif agar selalu mensyukuri bentuk tubuh yang dimiliki.

\section{Daftar Pustaka}

Azwar, S. (2012). Metode Penelitian. Yogyakarta: Pustaka Pelajar.

Cash, Tf, \& Pruzinsky, T. (2002). Body image: A handbook of theory, research, and clinical practice.

Cash, Thomas. (2012). Encyclopedia of Body Image and Human Appearance. https://doi.org/10.1016/B978-0-12-384925-0.09001-5

Costello, A. B., \& Osborne, J. W. (2005). Best Practices in Exploratory Factor Analysis: Four Recommendations for Getting the Most From Your Analysis. Practical Assesment, Research and Evaluation, 10.

Grogan, S. (2008). Body image : understanding body dissatisfaction in men, women and children. London: Routledge.

Hannan. (2018). Peran Citra Tubuh terhadap Konsep Diri dan Penerimaan Diri pada Siswa SMK Di Kecamatan Semarang Barat.

Mukhlis, A. (2013). Berpikir Positif Pada Ketidakpuasan Terhadap Citra Tubuh. Jurnal Psikoislamika, 10(1998), 5-14.

Singh, A. K. (2006). Test, Measurement and Research Methods in Behavioral Science. New Delhi: Bharati Bhawan.

Smolak, L., \& Thompson, J. K. (2011). Body Image, Eating Disorders, and Obesity in Youth: Assessment, Prevention, and Treatment (2nd editio). 
Aina Putri Khairani, Hannan, dan Laura Amalia

Sugiono. (2009). Metode Penelitian Kuantitatif, Kualitatif dan R\&D. Bandung: Alfabeta. 